\title{
Continuity and Discontinuity of Health and Health Care in the Czech Lands during two Centuries (1800-2000)
}

\author{
Petr Svobodný, Helena Hnilicová, Hana Janecková, \\ Eva Krízová and Hana Mášová
}

\section{Introduction}

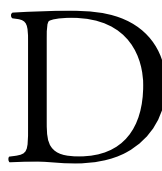

uring the last two hundred years the Czech Lands have undergone not just socio-economic changes but also dramatic political upheavals. We describe the connection between social and political transformation on the one hand and the state of health of the population on the other from the end of the $19^{\text {th }}$ century to the present with two main aims: Firstly, to show the clear continuities and discontinuities of health trends on our territory, and secondly to provide at least basic data for comparison with other countries. The emphasis is placed on the transformation period 1990-2000, during which the impact of political, economic and social changes on the health of the population and the quality of life have been the most obvious. The text presented is the collective work of five authors (historians and sociologists), who approach the theme from different standpoints. 


\section{General Overview $^{1}$}

\section{Historical Development}

The Czech Republic (CR) is a very young state, proclaimed in its present form only on the $1^{\text {st }}$ January 1993. Previously its territory (the historical lands of Bohemia, Moravia and Silesia) had been part of the Austrian Empire (1526-1918) and then Czechoslovakia (1918-1992). Political changes in the Czech Lands (or the states that they used to be a part of) often had a strong influence on the health of the population, as did economic and social change. For example, the roots of the modern health care system can be identified in the large-scale reforms carried out by the enlightened Habsburg monarchs from the 1750s. The substantial reforms of the health system were part of efforts to transform the Habsburg Empire from a backward feudalistic absolutist monarchy into a constitutional monarchy with a developed civic society (especially in its western part). Despite its striking cultural and economic progress, especially from the 1860s, the political emancipation of the Czech people in the multi-national monarchy was restricted by ethnic tensions or even open conflicts between the Czech majority (2/3) in the Czech Lands and the German minority, which was in many ways privileged by the centralising policies of Vienna. This was partially resolved with the establishment of the Czechoslovak Republic in 1918.

In addition to the economically, socially and culturally advanced Czech Lands (provinces of the former Austrian part of the monarchy) the new republic also contained the less economically and socially advanced (including the level of health and standard of health infrastructure) Slovakia and Ruthenia (originally integral parts of Hungary). The continuing tension between the state "Czechoslovak" nation (and indeed between Czechs and Slovaks despite their supposed union within the new nationality) and the national minorities (especially the Germans) proved a burdensome legacy. The establishment of the Republic was the first of many social-political upheavals throughout the $20^{\text {th }}$ Century. Other include: the transition from monarchy to republic (1918), the end of democratic republic (1938) and the Nazi occupation (1939-1945), reconstruction of pre-war conditions and short period of so called "limited democracy" (1945-1948), the beginning and the end of the totalitarian, Soviet-oriented communist regime (1948-1989), the beginnings of new democratic era after 1989, and the break-up of Czechoslovakia in 1992/93. All these events can also be understood as milestones of transition in the

1 (P. Svobodný, E. Krízová, H. Hnilicová, H. Janecková). 
health care system. Every new regime declared its own health policy, but real changes in the system was often a very different matter.

\section{Socio-Economical Development}

After the removal of political barriers industrialisation proceeded at high speed during the 1870s. As a result we can characterise Czech society at the turn of the $19^{\text {th }} / 20^{\text {th }}$ century as industrial-agrarian (like Lower Austria), in contrast to the surviving predominantly agrarian-industrial societies in the other Austrian provinces and the purely agrarian society of the Hungarian part of the monarchy. The industrialisation of the Czech Lands coupled with the change in the social structure of the population during the first half of the $19^{\text {th }}$ century resulted in a new distribution of economic, social and, by extension, health conditions and problems. This was compounded by increasing urbanisation, both in the sense of a rising number of larger settlements, and in the sense of a growth in their populations, during this time. The other side of industrialisation and urbanisation in the $19^{\text {th }}$ century was growing migration and emigration.

In the period of the $1^{\text {st }}$ Czechoslovak Republic (CSR, 1918-1938) we can characterise the Czech Lands as an industrial-agrarian society, with a high proportion of industrial working class (over 50\%) with an important middle class (especially amongst the civil service). The post-war revival of the Czechoslovak economy was faster than in the surrounding countries; in 1924-1929 it experienced a strong boom, especially in the Czech Lands. In the autumn of 1929, however, the CSR was hit by the world economic crisis (causing a steep rise in unemployment, peaking in 1933). Naturally the crisis had serious social and political consequences, and its negative effects on the health of the population require further research.

More dramatic changes in the structure of employment and the social structure, as well as changes in the regional distribution of population (migration to major industrial centres) took place after 1945, and then after 1948 with the political and economic measures taken by the communist regime (liquidation of the private sector, the reconstruction of industry with an emphasis on heavy engineering, planned economy, the orientation of foreign trade to the USSR and its satellites, the collectivisation of agriculture). Despite initial successes, the centrally directed and planned economy of socialist Czechoslovakia was already running out of breath by the late 1950s (a plan for economic reforms was one of the starting points of what was known as the "Prague Spring" of 1968). Its increasing economic problems in the 1970 s and 1980 s contributed very significantly to the collapse of "real socialism" in 1989.

The new Czech Republic also experienced a major socio-economic transition in the last decade of the $20^{\text {th }}$ century. After the political changes a market-oriented 
economy was re-introduced based upon massive privatization of national industries. The economy as a whole has been structurally reoriented from heavy industry towards the consumer and the construction industry, which involves small businesses and the development of a tertiary sector. Although viewed as generally positive, this restructuring has created unemployment, which is a new phenomenon after 40 years of full employment ensured by the communist regime. The economy has also suffered heavily from an underdeveloped and insufficient banking sector. In 2000 the gross domestic product of the CR was approximately 3 to $4 \%$ less than it was in 1989-1990. In spite of some negative trends, there are also positive signs of economic development. Labour productivity has increased by about $10 \%$ since 1990.

Political transition in 1989 also brought many changes in the everyday life of Czech citizens - freedom of movement and travelling, freedom of assembly, new civic associations and institutions, freedom of conscience and speech, freedom of beliefs and political orientations etc. On the other side, the economic aspects of transformation have caused a new type of injustice and inequalities, unemployment, wealth and poverty, winners and losers. Undoubtedly, all the social changes mentioned have had a strong impact on the quality of life of Czechs.

\section{Demographic Development}

The demographic trend in the Czech Lands in the earlier $19^{\text {th }}$ century can be characterised as one of long-term, relatively stable growth, especially compared to the catastrophic developments up to the end of the 1780s. Acceleration in population growth is particularly clear from the beginning of the 1820 s, with a later period of stagnation caused by World War I and a fall as a result of World War II (casualties, movements of population). A renewed gradual growth in population set in at the end of the 1950s and speeded up at the turn of the 1970/1980s, only to stagnate and even start to fall from the turn of the 1980/1990s. Up to the beginning of the $20^{\text {th }}$ century the result of the generally favourable development was a classic stable age structure characterised by a low age pyramid with a broad base, which did not change until WWI. The overall upward trend of population included structural changes in natality and mortality rates, and even large-scale emigration did not threaten it. Thus the population of the Czech Lands grew from roughly 4.3 million in the mid-1780s to 6.8 million at the end of the 1840 s to 10.1 million before WWI (the same before WWII), with a drop to 9.3 million in 1945, and recovery of the pre-war level (10.1) in the later 1970s to its current level of 10.3 million.

The originally high natality rate (42-44 live births per 1000 population with the exception of the period of the Napoleonic Wars) fell in the mid 1820s and until the 1870 s oscillated around $37-40$ per mille. From the 1870 s a long-term trend of 
decline set in (from 39 in 1870s to 35 in the 1890s and 28 by 1915). A steep decline set in during the $1^{\text {st }}$ World War and natality continued to fall to the level of 15 in the mid-1930s. During the $2^{\text {nd }}$ World War there was a revival in the birth rate and another short-term baby boom set in after 1945 (in the later 1940s it exceeded 21 per mille). From the beginning of the 1950s natality once again declined. Sparked by the enlarged social and maternity benefits as a part of the political and social "normalisation" strategy after the 1968 crisis the early 1970s witnessed an exceptional baby boom. Since the mid-1970s population peak (around 17 per mille) the decrease in live births has been constant with an accelerated regression after 1989 (the current level is 8.8 per mille in 2001, while total fertility rate decreased from 1,9 in 1990 to 1,1 in 2001). In the transition period of the 1990 s the number of live births was approximately only 50\% of the mid-1970s. In 2002 the drop in natality has slowed down slightly as a consequence of the large population cohorts of the 1970s baby boom reaching fertile age.

The trend in mortality (number of deaths/1000 population) has exhibited much more dramatic swings especially in the $19^{\text {th }}$ century. At the turn of the $18^{\text {th }} / 19^{\text {th }}$ century the mortality curve oscillated at the very high level of between 30 and 40 per mille, with high levels during catastrophes - wars, famines and epidemics (1796-1802 smallpox, 1805-1814 Napoleonic Wars accompanied by epidemics of smallpox and typhoid, absolute peak - 57 per mille - in the year of the Battle of Austerlitz 1806). From the beginning of the 1880s there was distinct and definitive change to the better; a drop in mortality from 29 per mille (early 1880s) to 19.5 just before the World War I (but naturally with a short-term rise during the war itself), and this continued into the 1920s and 1930s (reaching a minimum of around 13 per 1000 population in the mid-1930s). After a short-term rise in the early 1940s (WW II) the mortality rate once again fell (to between 10-11 per mille in the 1950s-1960s), only to rise in the 1970s-1980s (12-13 per mille). After 1989 a stable decline in mortality set in with the present mortality at 10.5 per mille in 2001 . Since 1994 the number of deaths has consistently exceeded the number of births and a natural population decrease has been slightly reduced only thanks to a positive migration balance. The process of population ageing implied by the long-term drop in natality and increasing life expectancy continues and is expressed by a crescent age preference index (i.e. the number of persons aged $65+$ years per 100 children up to 14 years) that achieved 87.0 in 2000. Life expectancy in both sexes has increased notably during the 1990s and has reached 72.1 years in males and 78.5 in females.

For almost the whole $19^{\text {th }}$ century infant mortality (number of deaths per 1000 live births) in the Czech Lands was extremely high in comparison with the other European countries. From the 1820s to the early 1890s it oscillated between 240 and 265 per mille. Variations in infant mortality did not, however, follow the curve of overall mortality (one reason was probably that natural immunity of infants protected them in times of epidemics). The mid-1890s saw a fundamental change 
for the better and infant mortality gradually (even if with a delay compared to the rest of Europe) fell to 189 per mille before the WW I. The falling trend (after a temporary reverse in wartime) continued under the First CSR (from 155 per mille at the beginning of the 1920s to 96 at the end of the 1930s). The substantial drop from the early 1950s was attributed to the successes of the new socialist health care system (from a post-war 87 to 47 per mille at the beginning of the 1950s to an average of 11.5 in the later 1980s). Another major improvement was visible after 1989 as infant mortality dropped again (from 11 in 1990 to 4.0 in 2001).

During the transformation era of the 1990s a decline in the number of marriages (the lowest since 1918) and, conversely, an increase in the divorce rate have been observed. The number of children born to cohabiting couples is continually growing. A positive sign of the demographic development of the 1990s is a continuing and stable decline in numbers of legal abortions. In summary during the 1990s the CR has gradually progressed towards the so-called western demographic model thanks to decreasing mortality, a drop in natality, abortion and marriage rates. The only deviations from the model are the ongoing high divorce rate and the instability of families with small children.

\section{Structures, Principles, Institutions ${ }^{2}$}

\section{The Health of the Population 1800-1945}

Systematic identification of rates of morbidity and mortality from individual kinds of disease is extremely difficult at least for the first and to some extent even for the second half of the $19^{\text {th }}$ century because of the ambiguity and changeability of period classifications of disease. More complete data on disease specific mortality in the Czech Lands make it possible to identify a turning-point in the incidence of these lethal diseases from the 1880s as a result of improvements in hygiene conditions in the larger towns and reforms in the health system: the last cholera epidemic in 1866, the last smallpox epidemic in 1872-73 (sharp fall in incidence from the beginning of 1890), the last epidemic of diphtheria 1877-78. Tuberculosis remained a continuing threat.

While changes of population as a rule reflect political and social changes, territorial changes and differences are also important. Different regions of the new Czechoslovak Republic followed their own development path and differed

2 (H. Mášová, E. Krízová, P. Svobodný). 
considerably in their economic and health-care level for a long time. The situation shortly after 1918 was characterised by the immediate consequences of the war increased incidence of infectious diseases (tuberculosis, typhus, cholera, sexually transmitted diseases and Spanish influenza) and physical exhaustion and pauperisation of the population, resulting in extensive malnutrition. The health condition of the population in the CSR was not in keeping with the economic and cultural level of the country. For instance, the rate of neonatal mortality and incidence of tuberculosis could not bear comparison with European standards. Even here, the contrast between the eastern and western provinces of the country was striking. The higher population increase (accompanied by higher emigration) in Slovakia and Ruthenia can be explained in terms of the less developed agrarian society of these regions.

The accuracy in establishing the cause of death was rather uneven, both for particular years and in particular parts of the country. The incidence of epidemic typhus (besides infant mortality, an indicator of poor hygiene) was sporadic and always due to foreigners in the western part before the war. After the war it was completely eradicated there. In the East it was endemic in the indigenous population (like trachoma); after the war, the epidemic nature of the disease was suppressed but the hazard persisted, also because of the risk of transmission from the Baltic region and the Balkans. Typhus and paratyphoid also ranked among the most serious health problems. Typhoid was of a somewhat endemic nature in prewar Bohemia and decreased at the turn of 1930. In rural regions of Slovakia and Ruthenia the incidence of typhus was much higher, though there was a considerable decrease in comparison with the pre-war period and the large wartime epidemics. The mortality for typhus was several times higher than in Western Europe, but lower than in Spain or Italy for instance. The tuberculosis rate in some parts of Czechoslovakia was among the highest in Europe at the beginning of the $20^{\text {th }}$ century (TB ceased to be a threat to the Czechoslovak population only in the early 1960s.)

By the mid-1930s infectious diseases mainly infested the economically and socially less advanced eastern regions of the country as well as the northern regions of the west, where industry was concentrated. In the early 1930s the main causes of death changed and mortality from infectious diseases rapidly declined in the western parts of the CSR (in Slovakia later - after World War II). The so-called "diseases of civilization" (cardiovascular and oncological diseases) began to prevail in the Czech Lands at that time.

The relative order of causes of death kept changing in the following years. Infectious diseases, including TB as the most lethal, moved from the second and third position in 1937 and 1948, respectively, to as low as the sixth position in 1959. Cardiovascular diseases (more in men), which had been a major cause of death even before the World War II, moved upwards on the list after the war. Neoplasms 
became the second most frequent cause of death (more in women). Two other groups became a serious problem: diseases of the nervous system (including strokes, taking third place) and - even more seriously - accidents (including poisoning), which affect the younger age groups of men. The differences between Slovakia and the Czech Lands persisting in the 1950s mainly reflected a different structure of population. By the end of 1950, there were still fewer neoplasms, neurologic disorders, cardiovascular diseases and accidents among the causes of death, but more infectious, respiratory and early age diseases in Slovakia.

After World War II, "well-being" was encouraged by the hope that a socially and economically fair society would overcome old miseries. In the second half of the century the diseases connected with other than external social factors (although the inability to overcome pollution and an unhealthy way of life is also related to social organization), took top positions in statistical tables of morbidity and mortality. The differences between the East and the West of the country and between its urban and rural parts were systematically equalized, health care was nationalized, but everybody's life was potentially affected by a new menace - by the Cold War and its ideological and economic consequences.

\section{The Health of the Population 1945-1989 and during the Transition Period of the 1990s}

Between 1945 and 1960 a remarkable improvement of the health of the population was achieved for every age group, partly due to better social conditions (peace, employment, welfare state) and partly thanks to the state-run health care system that made health care services universally accessible. Not only were financial barriers to healthcare abolished, but the state also took steps to ensure a balanced geographical distribution of health care providers by establishing the network of district and local polyclinics and also through a directive employment system that sent young physicians to insufficiently covered areas. Life expectancy began to rise and a continuous decrease in the incidence and prevalence of many diseases was documented in all population groups. From 1960, however, the positive development of the population health stagnated; no additional improvement was achieved despite new investments in the healthcare sector. The 1980s witnessed the culmination of years of slow decline and was documented in a highly critical report by local experts (though this report was accessible only to the leaders of the Communist Party). Life expectancy in both sexes lagged behind Western Europe, and was associated most obviously with excessive cardiovascular mortality in middle-aged men (50-60 years) as well as the increasing burden of other chronic diseases. Diseases of the circulatory system were responsible for more than half of the total mortality. The incidence and prevalence of diabetes, cancer, cardiovascular 
diseases, allergies, mental and muscosceletal disorders had grown quickly in all population groups, including children, despite the universal accessibility of health prevention and health care under state direction. The conclusion was that the socialist health care system had exhausted its potential benefits and could no longer motivate either the population or the providers. The paternalism of the socialist state had deprived citizens of a feeling of co-responsibility for their health and led to a passive attitude. Hence, one of the main explicitly declared goals of the transformation of the healthcare system after 1989 was an improvement of the general population health and a decrease of mortality and morbidity indicators.

The separation of health funding from the state budget and establishment of public insurance companies in 1991-1992 led to an unusual input of resources during the early transformation period. Modern technological resources were quickly enlarged and the latest technological interventions as well as pharmacological options introduced on a mass scale for the treatment of many diseases (see below). Further, positive changes in lifestyle as well as the democratic climate characterised by civic freedom also influenced the population's health, if in a less measurable way. The prevalence of smoking has slightly decreased, but on the other hand the abuse of illicit drugs has increased. Generally speaking, the motivation for health in an achievement-orientated society has been restored to a considerable extent, especially among the young and middle-aged. Although the number of people with a high BMI and a sedentary lifestyle increased between 1993-1999, there has been a noticeable improvement in dietary habits indicated by lower intake of meat and animal fat. Recently, the mass media has contributed substantially with articulation of health topics with new and more trustworthy coverage.

A remarkable decline in mortality and a rapid increase in life expectancy have been documented during the transition in the 1990s. Not only has crude and standardised mortality declined, but specific mortality from circulatory, respiratory and gastrointestinal diseases, neonatal and infant mortality have decreased as well. A slight drop in the suicide rate is evident, too, but the trend is oscillating. The number of deaths from malignant neoplasms as the second main mortality cause has stagnated. Since 1990, a dozen new cardiosurgery centers has been established in the $\mathrm{CR}$, so that in each region the newest cardiosurgical interventions are currently available. The total number of cardiosurgery operations rose from 1610 in 1989 to 10797 in 2002 . This change in the availability of cardiosurgery technology is most probably responsible for the drop in cardiovascular mortality and accounts for a large part of the increase in life expectancy. Men in the age group 60-69 years and females in the age group 70-79 years contributed most to the life prolongation (1/3), almost $1 / 2$ of the total gain between 1989-1995 is attributed to cardiovascular 
diseases. ${ }^{3}$ The overall gains in life expectancy between 1990 and 2001 were 4.5 years for men and 3.1 for women and life expectancy currently reaches 72.1 in men and 78.5 in women (Figure 1). Unfortunately, this positive potential was to a certain extent mitigated with an increased mortality in the traffic incidents in males 0-69 years and females in all age groups $(1-80+$ years $){ }^{4}$

On the other hand, the burden of chronic disease as documented in the late 1980s has remained essentially unchanged. There has been a positive trend in relation to infectious diseases only. The mean percentage of incapacity for work has increased as average duration of sick leave in days gets longer - while in 1985 mean percentage of incapacity for work was 4.45 , in 2000 it was as much as 6.46 . The number of people on full invalidity benefits has stagnated, whilst the number of people on partial invalidity benefits has risen. The incidence of malignant neoplasms and diabetes has increased continually in both sexes. Although the average length of a hospital stay has been reduced, the number of hospital admissions has risen by $21 \%$. An increase in the need for psychiatric care and the total number of first consultations in out-patient psychiatric departments was also observed during the 1990s. The subjective perception of health status has not changed notably over the last decade and, viewed comparatively, it still lags behind the European average. Thanks to very low neonatal and infant mortality the number of congenital and developmental defects in children per 10000 live births as well as the number of children followed up (dispenzarised) has increased steadily.

We may assume that the transformation had an uneven impact on the improvement of the health of the population. Some population groups benefited from the technological investments in health care and from the social change disproportionately, while the health of others deteriorated partly for social reasons (loss of state paternalism ${ }^{5}$ and lack of personal responsibility for health), and partly for specific structural reasons of the transformation policy (neglect of low priority diseases as mental diseases, for example).

3 J. Blažek, D. Dzúrová, 'The Decline of Mortality in the Czech Republic during Transition: A Counterfactual Case Study' in The Mortality Crisis in Transitional Economies, G. A. Cornia, R. Paniccia (Oxford University Press, 2000), 312.

4 Blažek, Dzúrová (2000), 312.

5 Blažek and Dzúrová document an increasing disadvantage caused by the marital status during the last decades (1960-1995) that has an impact on higher mortality rates especially of divorced and widowed men (Blažek, Dzúrová, 2000:313). This may show a changing role of state and family in providing social support and copying with everyday life. 
Figure 1. Life expectancy at birth, 1960-2002.

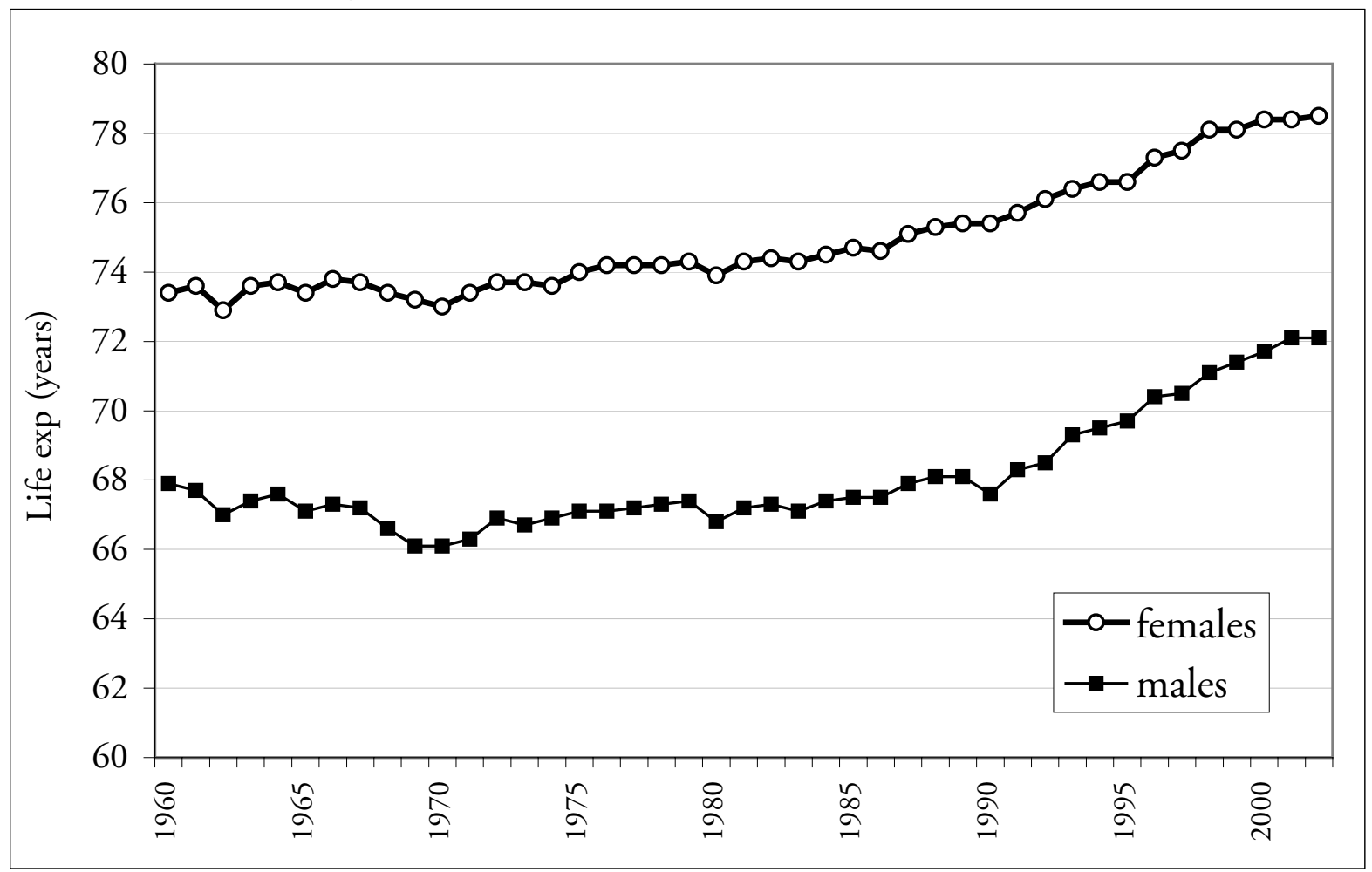

Source: Czech Health Statistics Yearbook, Institute of Health Information and Statistics of the CR.

\section{Health Care System 1800-1918-1948-1989}

The Habsburg rulers provided the basis for the later system of public health care with the establishment up of a court (imperial) health commission (1752). Simultaneously the monarchy issued "general health regulations" for individual provinces that included definition of the powers and responsibilities of different categories of health workers, especially in the field of preventive care (i.e. in periods of epidemics). In 1770 the provincial health regulations were augmented by a central Imperial Health Act. The shortcomings of the system, which had little effect at lower levels, were made very apparent in the 1830s when the first cholera epidemic broke out. In Bohemia one response was the drawing up of a reform plan involving the establishment of smaller health districts with their own official physicians. Similar proposals for establishing district and community doctors emerged in connection with administrative reforms after 1848. Basic health reforms were only made possible, however, by the change in political conditions after the fall of Austrian Neo-Absolutism. 1870 saw the issue of a new Imperial Health Act. But political obstruction on the part of Czech politicians and doctors, who were at loggerheads with their German-speaking equivalents, meant that the appropriate provincial health laws (for Bohemia, Moravia and Silesia) were only accepted after 
some delay (1880/1890s) The provincial health laws applied the principles of the imperial law in concrete form; they included introduction of the institution of official (state) doctors in political districts and in specially defined health districts, thus substantially increasing and extending access to medical care. Medical care was also rendered more accessible to the poorer classes by legislation making injury (1887) and sickness (1888) insurance compulsory in the Austrian monarchy on the Prussian model. From the end of the $19^{\text {th }}$ century other developments that contributed greatly to the improvement of health care for a ever wider sections of the population included the proliferation of voluntary societies and organisations, the growing number of doctors in private practice, the rapidly growing network of public and private hospitals and, of course, the advancing diagnostic and therapeutic resources of modern medicine.

The $1^{\text {st }}$ CSR saw a general trend to the improvement of the quality and expansion of existing structures (the setting up of the Ministry of Public Health; the extension of compulsory sickness insurance to other sections of the population; rise in the number of health facilities and numbers of staff etc.) and their extension to less advanced areas of the republic (Slovakia, Ruthenia) rather than the reconstruction of the health system as a whole.

The war period (1939-1945) brought a great many institutional and organizational changes in the structure of the healthcare system in the Protectorate of Bohemia and Moravia, all of them introduced without any discussions by the Protectorate or Nazi authorities. At the same time, both underground activists and representatives of the Czechoslovak nation in exile prepared their programs of postwar recovery and reform of the healthcare system. The healthcare system in liberated Czechoslovakia was returned to its inter-war form. The question of health reforms according to the plans of inter-war reformers, the plans of the governmentin-exile and its experts in London or the plans of the (not only) communist underground were still open. Trials, hesitations, partial reforms due to differing opinions concerning the future form of public health care were typical for the years $1945-1948$.

The communist takeover opened up the way for far-reaching health care reforms, which followed shortly after February 1948. These were nationalisation, unification, and centralisaton of the health care and social insurance system. This put an end to jurisdiction disputes, and was followed by an immediate series legal acts carrying through the socialisation of the health service. Nationalised hospitals, spas and sanatoria were incorporated into the Institutes of National Health. Prophylactic measures against TB and communicable diseases, based on legislation of the same year, were backed by restrictive powers but at the same time provided social security to invalids and their families. The National Insurance Act, for which socialist parties had struggled for so long, could be implemented according to communist concepts from that time on. 
By the early 1950s, the system of so-called unified hospitals was complete. In keeping with the principle of integrated health care in the health community system, hospital specialists took care of a hospital's catchment area, which was divided into health care districts. In close association with the hospital, the Institute of National Health (district, works and school health centres: out-patient facilities) pursued therapeutic as well as preventative functions, with a stress on prophylaxis. The discrepancy between prophylaxis and therapy was solved in an administrative way. The so-called "socialist" health care system in Czechoslovakia between 1948 and 1989 was officially declared to be one of the best in the world, "completely different" from the systems that had existed in Czechoslovakia before 1948, 1938 or 1918.

The health and social policy of the government seems to be the important factor influencing the health of population. Socialist Czechoslovakia can serve as an argument in this respect. In a centrally directed authoritarian society after 1948 it equalized the differences in the health of the population between the Czech regions and Slovakia much more rapidly than during the period of the pre-war democratic CSR. The causes of changes can be seen in more sophisticated instruments of medical science, shifts in the social situation of the population, ongoing industrialization and equalization of rural and urban life styles. But the changing role of the health service was essential, with the more consistent integration of prophylaxis and treatment, that had not earlier been required by, or promoted so vigorously, the prewar government.

It was in TB and maternity and child welfare centres that social medicine made the best progress. The disastrous postwar demographic situation and the lack of doctors provided the stimulus for the acceleration of other measures to support children, infants and mothers. Nationalization and unification of health consultation in 1947 was based on this urgent need of the day but - at the same time - prepared the ground for further fundamental measures in the sphere of prophylaxis. Being transferred under direct state administration and implemented by regional authorities (National Committees), it took the form of state-controlled popular institutes of national health.

\section{The "Velvet" Transformation of the Czech Health Care System in the 1990s}

The socialist health care system was subjected to heavy criticism in the late 1980s as a part of the "perestroika" movement. Poor population health was indicated by stagnation in life expectancy and an excessively high rate of chronic diseases. From the economic view, long-term underfunding and the growing black market for scarce services or drugs were criticised as well as the production-line character of 
healthcare services. The healthcare system transformation was from the very beginning an integral part of the global social transformation. As a political priority it was initiated immediately after the 1989 changes and approved by the government (1990) followed by fundamental legal changes (1991-1992). With respect to historical and cultural tradition, re-establishment of the Bismarckian mandatory health insurance was considered to be the best reform strategy. While universal access to healthcare services on the basis of needs and social solidarity remained the proclaimed principle (as it is guaranteed by the Charter on the Basic Human Rights and Freedoms that is a part of The Constitution) the main transformation strategy consisted in privatisation of ambulatory (outpatient) healthcare services, introduction of health insurance companies, and decentralisation of payers and providers:

- health insurance is mandatory (compulsory) for each earner, a state subsidy is paid for non-earners, so that the total population is covered with the health care;

- nine public health insurance companies are responsible for financing and contracting the care - a regular redistribution process from $60 \%$ of their budgets was introduced in order to prevent cream skimming;

- general practitioners and ambulatory (outpatient) specialists became private providers who contract with health insurance companies about the volume of care and the reimbursement - a quarterly negotiation process is defined by law;

- general practitioners are paid mainly on a per capita basis, while outpatient specialists are reimbursed on the fee-for-service basis with a quarterly cap;

- the privatisation of hospitals was stopped, most hospitals remained public and are financed through budgets (volume of care and size of the patients population is controlled);

- the population is entitled to a universal and equal access to healthcare services on the basis of clinical need;

- rationing of expensive treatment options, waiting lists and restrictions in consumer's choice have re-emerged since the shift from fee for-service to prospective financing in hospital care (1997).

In the early period, strongly influenced by adoration of the market and neo-liberal ideology, the idea of competition among statutory health insurance companies and health care providers was central. The intention was also to enhance consumer choice and strengthen individual motivation to health and responsibility for health through drug and other co-payments. However, the market ideology based on competition, freedom and meritocratic justice was grafted onto an egalitarian culture and ethics. Therefore, two scarcely compatible views on the healthcare 
system (a rightist and leftist one) have developed without striving for compromise and negotiation. Gridlock at the political level also halted the reform process in the mid 90s. Under social democratic government (since 1998) the emphasis has been laid on equal access to healthcare free of charge, but the system suffers from unsustainability of the quality and accessibility achieved in the early 1990s given current economic resources. Recently, the issue of rationing expensive treatment and drug options as well as the debate on individual contributions at the point of use or via private coinsurance has re-emerged.

The Czech health care system has developed from a state-run tax-funded centralised system to a statutory public health insurance of Bismarckian type. No collapse of services occurred during the transformation period despite decentralisation and privatisation. On the contrary, in the early 1990s a general improvement of quality of care, accessibility of drugs and treatment modalities as well as an improvement of the physician-patient interaction was achieved thanks to an exceptional input of resources, an open market with devices and technologies and free choice of providers. Total health expenses grew from 4-5\% of GDP in the late 1980 s to $7-8 \%$ in 2001 . However, the increasing indebtedness of public insurance companies has led to public regulation and the reestablishment of administrative rules of the previous system (e. g. free hospital choice is restricted by the place of patient's permanent residence). Certain patient groups, namely those treated by the newest technologies have profited more than long-term patients like elderly or psychiatric patients. The system lacks a permanent supervision of quality and accessibility of care and cannot prevent lottery elements creeping in. Furthermore, even though the situation of patients has improved remarkably in the 1990s, patients' rights in their entire extent are still not fully respected and protected by autonomous institutions. Public hospitals suffer from the dissatisfaction of physicians and nurses. Currently, further steps must be taken in order to sustain the positive transformation achievements for the future.

\section{Social Change and Quality of Life 1990-2000 A Picture of the Impact of the Transition of Czech Society on the Quality of Life in Social Research ${ }^{6}$}

The concept of the quality of life has major consequences for public policy. Its assessment in specific population groups can provide useful information about the effectiveness of the socio-economic policy of the government. Additionally, it makes possible evaluation of the impact of various changes in the social, political

6 (Helena Hnilicová, Hana Janecková). 
and biological environment on the everyday life of people and on their perceptions of self-health. From this point of view it is important to know how individual members of the society perceive the life events and situations connected with global social changes and how they are ready to cope with new and often stressful life circumstances.

The transition from a totalitarian to a pluralistic political system in the Czech Republic was accompanied by great social and economic changes that represented social and life stress and substantial risk to both psycho-social and physical health. On the other hand, at the same time, some features protective of health could be observed, especially changes in nutrition habits and the quality of healthcare, which contributed significantly to the continuing improvement of the health status of the Czech population. All these processes have influenced the everyday quality of life and created the "winners" and "losers" of the new era.

\section{Losers and Winners of the New Era}

A research team of the $1^{\text {st }}$ Medical Faculty, Charles University Prague has attempted to identify the "losers" and "winners" of the rapid transformation in 1989-2000. The question was how people themselves experienced all the rapid social changes in the society. For this reason the project tried to identify the main attributes of the quality of life of the Czech population in the 1990s as well as to clarify the impact of the social changes on the subjectively perceived quality of life during the transition period. The survey was carried out in 2000-2001, investigating the quality of life of a random sample of the Czech population $(\mathrm{N}=1200)$. A questionnaire consisted of 49 questions. The majority were constructed as closed questions. Two open-ended questions were also included.

For the purposes of this research, the concept of quality of life was defined as the subjective assessment of the overall quality of life as well as subjective satisfaction with various aspects of life like family, partnership, friendship, job, personal autonomy, success and respect from others, financial situation, leisure time activities, appearance and body weight. Respondents also epressed their opinion on the impact of the transition on their financial situation, work opportunities, interpersonal relations, choices for leisure time, access to information, free opinions expression, professional engagement and job position, enjoyment of cultural events, participation in public policy and finally with the overall quality of life. The principal question was, whether the social changes had caused an improvement or deterioiration in the personal situation of the people. The perceived impact of the changes was analysed by gender, age, education and political orientation. A life 
Figure 2. Satisfaction with global quality of life by age (mean value of all items). Comparison of genders.

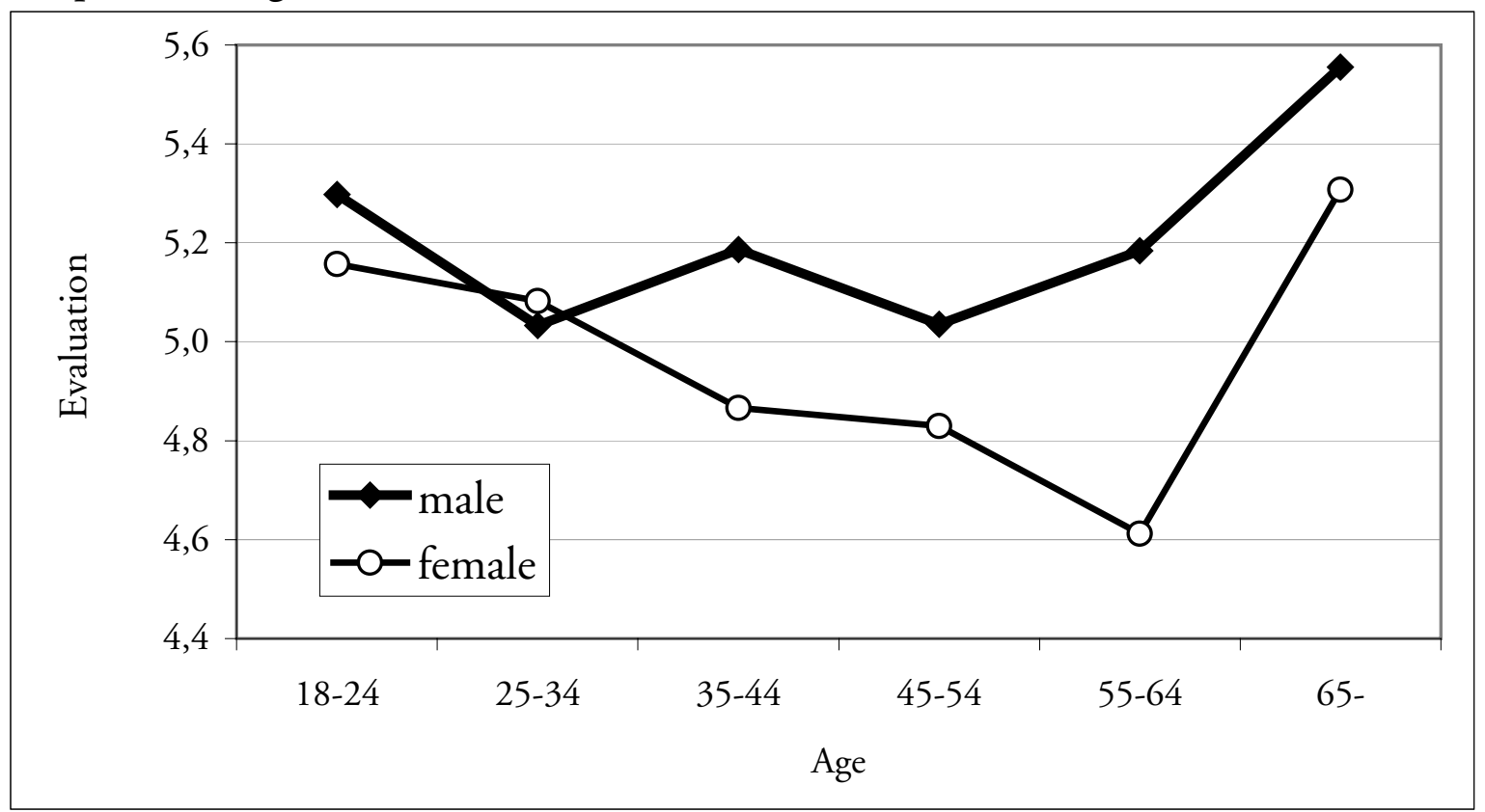

Commentary: Influence of the age on the satisfaction with global QoL is very significant (F $(1046 / 11)=2,39 ; p=0,006)$. Younger people are more satisfied than older people. Influence of gender is approximated to the level of significance $(F(1046 / 1)=3,75 ; p=0,053)$.

events analysis was also conducted. Self-reported health status was measured on the 5-point scale.

The results showed, that ten years after the political change, Czech people were in general more satisfied than unsatisfied, even if the perceived satisfaction was not very high. For the whole sample the mean value of satisfaction scored 5 on the 7point scale, described as "often satisfied". Czechs expressed the highest satisfaction with their friends and with their family life and the lowest satisfaction with their financial situation, body weight and physical appearance. The global quality of life differs between age groups. The least satisfaction with quality of life was found at middle age generations between 45-64 years. Women tended to be less satisfied than men. They were less satisfied especially with their life partners. It seems that Czech men have benefited more from partnership than women and that this lower satisfaction in partnership might contribute to the lower quality of life of women (Figure 2).

The most favourably assessed elements of social changes were "the possibility to express personal opinions freely", "availability of objective information" and "choices for leisure time". The changes in "economic situation" and "job opportunities" were rated less successful. The only item rated as having deteriorated with the transformation, was "interpersonal relations". Although Czechs expressed the highest satisfaction with their friends and family life, the development of relations in the society as a whole was not perceived as so good. On average both 
Figure 3. "Winners" and "losers" of the new era in the CR.

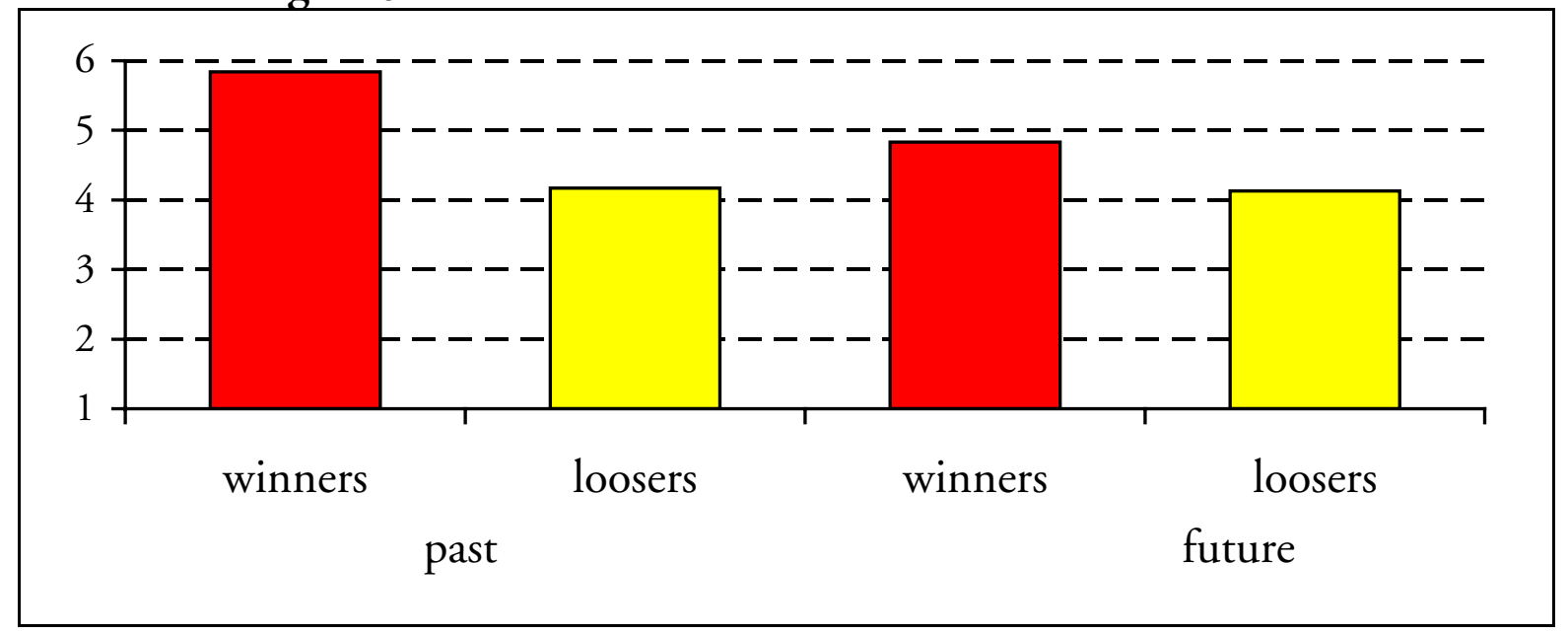

Commentary: "Winners" evaluated social changes as more positive ( $1=$ strong worsening; $7=$ strong improvement). Differences are very significant for evaluation of past changes (in the years $1989-2000) \mathrm{t}(133)=13,87 ; \mathrm{p}<0,0005$ as well as for expected changes in the future $\mathrm{t}$ $(128)=5,83 ; \mathrm{p}<0,0005$. "Winners" were men in the age 18-35 years, with university or at least high school education, with rightist political orientation. "Losers" were 45 and more years old women with elementary education or apprenticeship and with leftist political orientation.

men and women reported a mild improvement in the quality of their lives as a whole. The majority of the population (65\%) indicated that their life was better than before 1989 and only $12 \%$ felt that their life was worse.

The only item that both men and women appreciated highly was the newly gained freedom of speech. Men perceived higher improvement than women in all other items, especially in their possibilities "to achieve a better position at work". For Czech women the transition changes were less positive than for men. Younger people, respondents with higher education and with a rightist political orientation evaluated transition changes as more positive.

To express our findings in the terms of "losers" and "winners", it is possible to assume, that younger men, with higher education, a rightist political orientation and good health were the group of "winners", which gained the most from the political change. Older women with lower education and left political orientation could be assigned as "losers" of the new era in the Czech Republic. Figure 3 illustrates the conclusion proved by statistical analysis of the research data.

Life events connected with the Czech transformation were significantly correlated of these events with subjective health status. Changes of workplace, resettlement, property increase or restitution were closely related to the feeling of good health (Table 1). For healthy people these events were a challenge, while for people with poor health the negative life events undermined their positive activity. 
Table. 1. Economically related life events (\% of the whole sample)

\begin{tabular}{lcc}
\hline & $\mathbf{1 9 9 0 - 1 9 9 5}$ & $\mathbf{1 9 9 6 - 2 0 0 0}$ \\
\hline Changed employment & 34 & 41 \\
Removed & 20 & 24 \\
Increased property & 10 & 17 \\
Had a big loan & 3 & 8 \\
Received back property in & 4 & 1 \\
restitution & & 11 \\
Lost financially & 4 & \\
\hline
\end{tabular}

\section{Experience with Unfairness, Injustice and Inequality}

In spite of the rather positive picture of the Czech transformation after the collapse of the past regime, many disappointments and injustice were experienced in the lives of individuals. Respondents were asked about their understanding of the quality of life and their experience with aspects to unfairness, injustice and inequality. Content analysis of the answers made it possible to identity sources of perceived injustice that had arisen during the transition period:

a) The area of policy and law was very important for people. While freedom was mentioned in all age groups, the older people often stressed security and absence of worries for the future. The most important barriers were seen in the area of law. People generally perceived this area as a substantial source of inequity, allowing crime to go unpunished, whether fraud and corruption or the aggressiveness of drivers. Some of the older people completely missed any appreciation for what they had done "for society" during their lives. Younger people criticised the presence of racism, discrimination and the humiliation of women, impoliteness, corruption and protection.

b) The area of economy and work had impact on the life events lived by a great part of the population (Table. 1). The quantity of answers showed this area to be a substantial source of feelings of injustice. Having a good job and job satisfaction were stated as an important source of the quality of life. All the generations expressed dissatisfaction about the financial situation, specifically with low pensions, high prices, unfair competition, fraud and swindle, the asset-stripping of banks and enterprises, absence of rules, abuse of public sources etc. Moreover people suffered from stress and uncertainty at the workplace: older people experienced age discrimination, young people had limited opportunities in the labour market, women felt injustice in reward for work, wages were considered inadequate, others mentioned unfairness of the bosses, especially in the private sector. It is possible to conclude that from the health and the quality of life point of view the work environment seemed to be very stressful and threatening for the Czech people. 
c) Social transformation has brought income differences and new social stratification. The survey showed that gender and age might be considered a source of inequities. Good family relations, partner for living, good friends, respect and appreciation, help to those who need help were indicated as substantial determinants of the quality of life. The young and middle-aged also mentioned the quality of housing. As a basic source of injustice respondents indicated the division of society into the rich and the poor, social insecurity, bad relations in families, bad interpersonal relations at the work place, selfishness, unfair behaviour, intolerance, irresponsibility and stupidity.

d) From the point of view of health and living environment the transition has created new conditions, which may be either stressful or supportive. Older people especially often indicated health care and environmental conditions as the cause of inequities. They specifically criticised the impolite behaviour of doctors, waiting times, co-payments for health care and lack of information. These concerns were not present among younger generations.

\section{Conclusions}

In our research both quantitative and qualitative analysis provided very consistent results. In their answers the respondents indicated that interpersonal relations, financial situation, work and political climate were very important sources of the quality of life. In spite of significant reservations, the respondents expressed general satisfaction in the most of the analysed areas, although improvement was not very high, with mild deterioration in interpersonal relations. Higher social mobility was connected with economic and work insecurity and consequently with feelings of inequity amongst certain groups of population. In the field of work there were differences between men and women characterised by the lower job satisfaction of men and by a feeling of discrimination on the part of women. Women were also less satisfied than men with their overall quality of life.

Health was perceived as an important aspect of the quality of life, especially by older people. While for the elderly good health was primarily the absence of problems in physical health, young people emphasized psychosocial well-being. Healthcare and environment were, moreover, seen as a source of inequity and stress.

The radical change in 1989 has finally brought a better quality of life for the majority of Czech population. The lowest level of satisfaction was expressed by people between 45-65 years, who can be called the "lost generation". These people spent most of their lives under communism. Some of them had very high expectations from the new regime and later they were disappointed, while some of them did not have enough capacity, willingness or even health to adjust to the 
change. Quality of life was then determined not only by the life events that people experienced, but also by people's life objectives and internal capacities.

\section{General Conclusions}

Social, economic and health changes in the Czech Lands have been closely connected with the political changes especially in the $20^{\text {th }}$ century. In the second half of the century it is therefore very difficult to make an easy assessment of the causes of observable changes in the state of health of the population. It is not clear yet to what extent they were a reflection of the authoritarian measures taken by the communist regime that led to radical changes in the social structure, standard of living, the health service, and social values, and how far they resulted from longer term trends. Impacts on health may, after all, be observable only with a time lag due to the long-term processes involved, inertia and so forth. The long-term impact of the world economic crisis in the 1930s and WWII on indices of the state of health of the population also manifested itself with a time lag as late as around 1960. The exception was that of immediate reactions to social crises as expressed in suicide rates (a marked rise in suicides in 1930-1934,1945-49 and after 1968).

From the short-term point of view, the assessment of the changes since 1989 has been easier. Within an extremely short time demographic behaviour and changes in the structure of illness (in both the positive and negative sense) have aligned themselves with Western Europe. The reintroduction of a system of health insurance instead of state funding and the reorganisation of the health system on corporatist models instead of direct state management may be regarded, despite all the shortcomings increasingly evident recently, as one of the reasons for the relatively successful transformation of the Czech healthcare system. The return to tradition could not, however, be complete, socialist practice has not been entirely abandoned, and at the same time the influences of the globalised world economy and mentality have been manifest here as well. For this reason the outcome is a peculiar mixture of heterogeneous elements, which from certain points of view may seem dysfunctional. Some elements of Czech post-transformation society are entirely specific and have no parallel in western society.

The Longue durée (in the Braudelian sense) of the institutions, values and behavioural norms of Czech society, which have their roots in the last decades of the Habsburg Monarchy and in the $1^{\text {st }}$ Czechoslovak Republic, has been manifest in the field of health in the ability to resist the negative effects of the discontinuity of political regimes during the $20^{\text {th }}$ century. The impact of changes has been filtered by institutions across the whole range of the spectrum. Political changes have moreover been opportunities for the foundation of new institutions, which have further or 
embodied trends that originated in the womb of the preceding regime. In this respect the Czech Republic has avoided the kind of disintegration of institutions and abandonment of values that has occurred in other post-communist societies (for example Russia, and to a certain extent other east European countries like Rumania, but also Poland or Hungary) that have different traditions. The social capital of Czech society has also played a role here. One important component of the socially shared social capital was the existence of the independent state and the consciousness of national identity associated with it and the growth of civic society from the later $19^{\text {th }}$ century, expressed in abundant creation of clubs and societies (including in the social welfare and health spheres -1880s-1918, 1918-1938, 1989now). Although this element was perhaps the most suppressed under socialism, after 1989 it experienced immediate renaissance. The capacity to cope with change has also been strengthened by the tradition of universal access to education and professional qualification (from the $18^{\text {th }}$ century). An educated work force, a good standard of general education, respect for work and discipline as a moral value continue to characterise the Czech environment. Political parties likewise have a rich tradition in this country going back to the later $19^{\text {th }}$ century, and so it could be said that political affiliation is likewise a form of social capital, however, arguable (under the First Republic affiliation to political party affected more spheres than just politics, and for example towards the end of the socialist regime roughly $1 / 10$ of the population were members of the Communist Party).

Since 1989 there has been deep social differentiation, but indifference to sociallybased differences in health and access to health care have survived from the time of the "egalitarian society". Despite the well-grounded belief that social transformation has led to an accumulation of the effects of lack of education, poverty and unemployment in the form of poor health and higher mortality, these differences have not been sufficiently monitored. Regional differences in living standards, job opportunities, and distribution of positive and negative transformation effects also appeared to be enhanced. Since the social profits from the transformation have not been evenly spread, it is unlikely that the general improvement in health has been evenly spread or is something independent of social determinants. Although justice and equality is the proclaimed goal, in reality equality in health is essentially a taboo subject, since it is not empirically monitored.

From the point of view of the individual, social capital during the socialist era has consisted in a network of informal relationships that in the socialist period compensated for lacking market relations in distributing goods and services. After 1989 those who actively engaged in the process of privatisation and political life have profited from these networks. Another group of winners is composed of most of those who had family property restituted to them, and those who have managed to exploit their huge qualifications in market conditions (managers, computer specialists, lawyers). To sum up - young, healthy and educated people, particularly 
men, and particularly inhabitants of larger towns, have proved the most capable of turning the opportunity of change to their advantage.

Although the transformation after 1989 is still viewed more positively than negatively, since it represented a return to democracy, civic society and the revival of respect for fundamental civil rights and liberties, increasing inequalities in wealth, status and health could mean a future risk that might lead to the destabilisation of society and threaten democracy. For this reason it is a theme worthy of greater attention, from the point of view of research and the point of view of practical political decision-making.

Helena Hnilicová is Assistant Professor at the Institute of Social Medicine and Public Health $1^{\text {st }}$ Faculty of Medicine at Charles University, Praha, Czech Republic. Hana Janecková is Assistant Professor at the School of Public Health, Institute of Postgraduate Medical Education, Praha, Czech Republic. Eva Krizová, is Assistant Professor at the Institute for Medical Ethics and Nursing, $3^{\text {rd }}$ Faculty of Medicine at Charles University, Praha, Czech Republic. Hana Másová is Assistant Professor at the Institute for the History of Medicine $1^{\text {st }}$ Faculty of Medicine at Charles University, Praha, Czech Republic. Petr Svobodny is Associate Professor at the Institute for the History at Charles University, Praha, Czech Republic.

\section{Acknowledgements}

Research on this chapter has been financially supported by the Ministry of Education, Youth and Sports of the Czech Republic (project Research Centre for the History of Sciences and Humanities, LN00A041; project Quality of Life Goals of the Medicine, VZ 111100007), the Grant Agency of the Czech Republic (project Sociological Shifts in the Medical Profession, No. 403-02-0691), and the Grant Agency of Charles University (project Health Care in Czechoslovakia 19002000. Continuity and Discontinuity, Statements and Reality, GAUK 295/02). 


\title{
Selected bibliography
}

\author{
Historical Development
}

Krejčí, J., Czechoslovakia at the Crossroads of European History (London - New York, 1990).

Teich, M. (ed.), Bohemia in History (Cambridge University Press, 1998).

\section{Socio-Economic Development}

Sociálni politika [Social Politics], Ministry of Labour and Social Affairs of the Czech Republic,Vol. 29, 2003, No. 3, p. 1.

Zpráva o lidském rozvoji. Ceská republika 1999 [Report on Human Development. Czech Republic 1999], Výzkumný ústav práce a sociálních věcí, Praha 1999.

\section{Demographic Development}

\section{Statistics:}

Statistisches Handbuch der österreichischen-ungarischen Monarchie (since 1867)

Statistická príručka Králoustvi ceského [Statistic Handbook of the Bohemian Kingdom] (since1909).

Statistická ročenka Ceskoslovenské republiky [Statistic Yearbook of the Czechoslovak Republic, different titles], 1920-1992.

Statistická ročenka České republiky [Statistic Yearbook of the Czech Republic], since 1993.

Monographs:

Kárníková, L., Vývoj obyvatelstva v českých zemích 1754-1914, Praha 1965.

Kretschmerová, T., Šimek, M.: Populační prognóza České republiky do roku 2030 [Population Projection of the CR up to 2030]. Demografie, vol. 42, Nr. 3, 2000, p. 183-192.

Srba, V., Kučera, M., Vývoj obyvatelstva českých zemí v XIX. století, Statistika a demografie I, 1959, p. 109-154.

Stloukal, M., Maur, E., Fialová, L., Horská, P., Musil, J., Kučera, M., Dějiny obyvatelstva českých zemí, Praha 1998. 


\section{The Health of the Population}

Blažek, J., Dzúrová, D.: The Decline of Mortality in the Czech Republic during the Transition: A Counterfactual Case Study. In: Cornia, G. A., Paniccia, R. (eds.): The Mortality Crisis in Transitional Economies. Oxford University Press, 2000, p.303-327.

Bráf, A., Studien über nordböhmische Arbeitsvehältnisse, Prag 1881.

Dolejší, V., Jaroš, J., Stach, J., Ukazatele eskoslovenské zdravotni statistiky, Praha 1959.

Drbal., C., Albrecht, V., Zdravotní stav a zdravotní politika České republice [Health status and health policy in the Czech Republic], Zdravotnické noviny 25. 4. 1997, p. 8.

Health Interview Surveys, Institute of Health Information and Statistics, Prague 1993, 1996, 1999.

Jaroš, J., Kalina, K. (eds.), Czech Health Care System. Delivery and Financing. OECD Study. Czech Association for Health Services Research, Prague 1998

Mášová, H., Political Changes and Changes of Health: the Case of the Czechoslovak Republic Coping with Tuberculosis (1918-1989), Contribution at PHOENIXTN/MMF Workshop, Évora University, Portugal, $22^{\text {nd }}$ September 2002.

Pelc, H., Service d'hygiéne publique en Tchécoslovaquie, p. 1. 1923.

Singer, J., Untersuchungen über die sozialen Zustände in der Fabriksbezirken des Nordöstlichen Böhmen, Leipzig 1885.

Stř́iteský, J., Zdravotni a populačni vývoj československého obyvatelstva, Praha 1971.

Svobodný, P., The Health of the Population and Health Policy in $19^{\text {th }}$ Century Bohemia: The case of Asiatic Cholera (1830s-1900s), Contribution at PHOENIXTN/MMF Workshop, Évora University, Portugal, $22^{\text {nd }}$ September 2002.

Vacek, M., Mortality trends in Czechoslovakia, Vital and Health Statistics, ser. 3, No. 13, Washington D. C. 1969.

Zdravotnická ročenka československá [Czechoslovak Health Statistics Yearbook], 1928-1939/40.

Zdravotnická ročenka ČR [Czech Health Statistics Yearbook], since 1992.

Zdravotnictví ČSSR [Health-care in Czechoslovakia], since 1960-1992.

\section{Health Care System}

Den Exter, A., Health Legal Reforms in the Czech Republic and Hungary, in: Krízová, E., Šimek, J., Health Care Reforms in Central and Eastern Europe: Outcomes and Challenges. $3^{\text {rd }}$ Faculty of Medicine, Charles University, Prague 
and Institute of Postgraduate Medical Education, Prague, 2000, pp. 27-42.

Krízová, E., The Czech Health Care System Transformation at the Cross-Roads, in: ibidem, pp. 85-92.

Mášová, H., Nemocnice ve zdravotni a sociálni péči proni Československé republiky (The Role of Hospitals in Public Health Care and Social Welfare Policy of the 1st CSR), Dissertation, Prague 2003.

Možný, I., Proč tak snadno?, Slon, Praha 1999.

Svobodný, P., The Professionalization of Czech Physicians, in: McClelland, C., Merl, S., Siegrist, H. (eds.), Professionen im modernen Osteuropa/Professions in Modern Eastern Europe (Giessener Abhandlungen zur Agrar- und Wirtschaftsforschung des Europäichen Ostens, Bd. 207), Berlin 1995, pp. $145-167$.

Svobodný, P., Hlaváčková L., Dějiny mediciny v českých zemich [History of Medicine in Bohemia and Moravia], chapters 5-9 (1740-2000), Praha 2003, (incl. detailed bibliography).

\section{Quality of Life}

Antonovsky, A., Health Stress and Coping, Jossey-Bass, San Francisco 1979

Cambell, A., Converse, P. E., Rodgers, W. I., The Quality of American Life, Russel Stage, New York 1976.

Cockerham W. C., Medical sociology, 6th Edition, Engerwood Cliffs, New Jersey 1995, pp. 67-87.

Cockerham, W. C., Health and Social Change in Russia and Eastern Europe, Routledge 1999.

Hnilicová, H., Vymezení pojmu kvality života a její význam pro medicínu a zdravotnictví [Toward the Concept of the Quality of Life and its Application in Medicine and Health Care], Lékařské listy 2003, No. 5, p. 27-29.

Janecková, H., Transformation of the Health Care System in the Czech Republic -

a Sociological Perspective, in: Cockerham, W. C. (ed.), The Blackwell Companion to Medical Sociology, Oxford 2001, pp. 347-363.

Jaroš J. Kalina, K., Czech Health Care System. Delivery and Financing. Czech Association for Health Services Research Prague, OECD Study, January 1999

Názory občanů na zdravi a zdravotnictvi. IVVM Praha 1990. [Public Opinion Survey on Health and Health Care, Institute of Public Opinion Research], Prague 1990.

Research project of the $1^{\text {st }}$ Medical School "Targets for medicine - quality of life and the health", Charles University, Prague, 1999 - 2001, head of the project Jan Payne MD.

Sundin, J., Willner, S., Health and Social Transitions. The Swedish Case. 
Contribution at PHOENIXTN/MMF Workshop, Evora University, Portugal, $22^{\text {nd }}$ September 2002.

Siegerist, J., Health in the Workplace. Paper presented at the plenary session of the International Conference on Reducing Social Inequalities in Health, Copenhagen, 27-29 September 2000.

Statistic Yearbook in the Area of Work and Social Affairs, Ministry of Work and Social Affairs 2002. 